\title{
Preglacial geomorphology of the northern Baltic Lowland and the Valdai Hills, north-western Russia
}

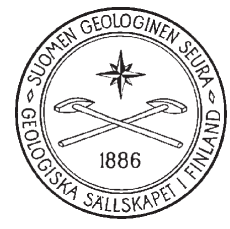

\author{
A.Y. Krotova-Putintseva and V.R. Verbitskiy \\ A. P. Karpinsky Russian Geological Research Institute (VSEGEI), \\ Sredny pr. 74, 199106 Saint-Petersburg, Russia
}

\begin{abstract}
The aim of the ongoing investigation is to reconstruct the development history of preglacial (including deeply-incised) river network of the northwestern East European Platform during the Cenozoic. This paper describes the orography of the region. The results of studying the structure of modern and preglacial (pre-Quaternary) geomorphology are given. This synthesis is based on the geological information that has been acquired as a result of systematic state geological surveying and scientific investigations and also on the analysis of published materials for the study area.

The hypsometric map of the pre-Quaternary surface is presented. Generalization of the above mentioned materials on a unified basis and at regional level allowed a new reconstruction of the preglacial river network in the IImen Lowland area, drainage from which to our opinion was to the west. Analysis of the preglacial and modern topography correlation shows that the latter, in general, is inherited. This leads to the conclusion on a quiet tectonic regime in the study area at least since the Mesozoic. Therefore, the question on the causes of deeply incised valleys requires further study.
\end{abstract}

Keywords (GeoRef Thesaurus, AGI): geomorphology, topography, paleorelief, preglacial environment, drainage patterns, rivers, Cenozoic, Novgorod Region, Russian Federation

Corresponding author email: avacha2001@rambler.ru

Editorial handling: Pertti Sarala

\section{Introduction}

During the Pre-Quaternary (preglacial) time, the north-western part of the East European Plain was drained by erosional channels, some of them below the sea level. Later, these paleovalleys were completely or partially filled with glacial, aqueoglacial, and interglacial deposits. Until now, there is no agreement on the formation time, initiation, and the exact location of the paleovalleys because, due to a long period of denudation since the Middle Mesozoic (for the entire territory), traces of the bygone geo- 
logical epoch are lost or veiled. The main goal of the ongoing research is to reconstruct the evolution of the drainage system of the north-western part of the East European Platform during the Cenozoic based on the geological structure of the territory. Reconstruction of the ancient river network should involve a unified and regional approach to the network formation history.

This paper presents the results of studying the structure of the modern and pre-Quaternary topography. Investigations were held in the framework of compilation of the State Geological Map at 1:1000 000 scale (third generation), sheets 0-35 Pskov (with N-35 part) and 0-36 - Saint Petersburg. Works on compilation of the State Geological Map at 1:1 000000 scale (third generation) were started in 2002. Total number of sheets to be compiled in the framework of this program is 246 , including land and continental shelf of the Russian Federation (Petrov et al., 2007).

\section{Study area}

The study area is located in north-western Russia within the East European Platform. It occupies the north-western part of the Russian Plate, and borders on the southern edge of the Fennoscandian Crystalline Shield. Western part of the area belongs to the Baltic Lowland, and the eastern part to the Valdai Hills that are $100 \mathrm{~m}$ to $346 \mathrm{~m}$ high (Fig. 1).

\section{Materials and methods}

Principle of the State Geological Map compilation at 1:1000 000 scale (third generation) requires integration of the State Geological Maps at 1:200 000 scale (first and second generation) and at 1:1 000000 scale (second generation) (Petrov et al., 2007; Burde et al., 2000). Therefore, all published sets of geological maps at 1:200 000 scale, as well as a map at 1:1000000 scale (second generation) for the study area and adjacent territories were used (Kirikov \& Yanovskiy 1989).

A database containing description of 2436 geological and hydrogeological boreholes was created. The database includes the borehole's number, coor- dinates, altitude of the mouth, depth and sediment characteristics, general and regional age. This database was used during compilation of hypsometric map of the pre-Quaternary sediments surface with $25 \mathrm{~m}$ interval isolines. Existing schemes of the preQuaternary surface structure from the above mentioned and published resources were considered during compilation of this map and the preglacial river network reconstruction (Malakhovsky \& Markov, 1969; Kvasov, 1975; Gibbard, 1988; Grigelis, 1991; Auslender, 1998; Vaher et al. 2010).

In process of research, the schemes of geomorphology, geomorphologic districts, glaciations, and glacial lakes were created. Publications of Markov \& Malakhovskiy (1969), Kvasov (1975), Goretskiy et al. (1982) etc., as well as the Quaternary geological map of the study area (authors V. Kyamyarya and V. Mokhov) were utilized.

\section{Modern topography}

\subsection{Orography}

The study area is situated in the north-west part of the Russian Plain. Sedimentary rocks have subhorizontal bedding and tectonic movements (if such exist) are characterized by moderate amplitude that is commensurable with exogenic processes (Malakhovskiy, 1995). This causes flat topography character.

Major orographic elements of the Russian Plain are the Baltic Lowland and the Valdai Hills (maximum height is $346 \mathrm{~m}$ ) (Fig. 1). The Baltic Lowland is a gently sloping to the north undulating plain, crossed by a dense network of rivers, with isolated highlands up to 200-338 m high. Along the southern coast of the Gulf of Finland, the Neva River and the southern shore of Lake Ladoga, there is a narrow strip of pre-glint or maritime part of the Baltic Lowland with surface elevation from 15 to $30 \mathrm{~m}$. The flat lowland topography is in some places complicated by small island elevations (Koltushy - 80 m, Vsevolozhsk - 50 m, Semeisky - 96 m, Soikinsky-137 m). The pre-glint lowland is bounded by the Baltic-Ladoga scarp or the Ordovician glint from the south. The glint is well expressed in 


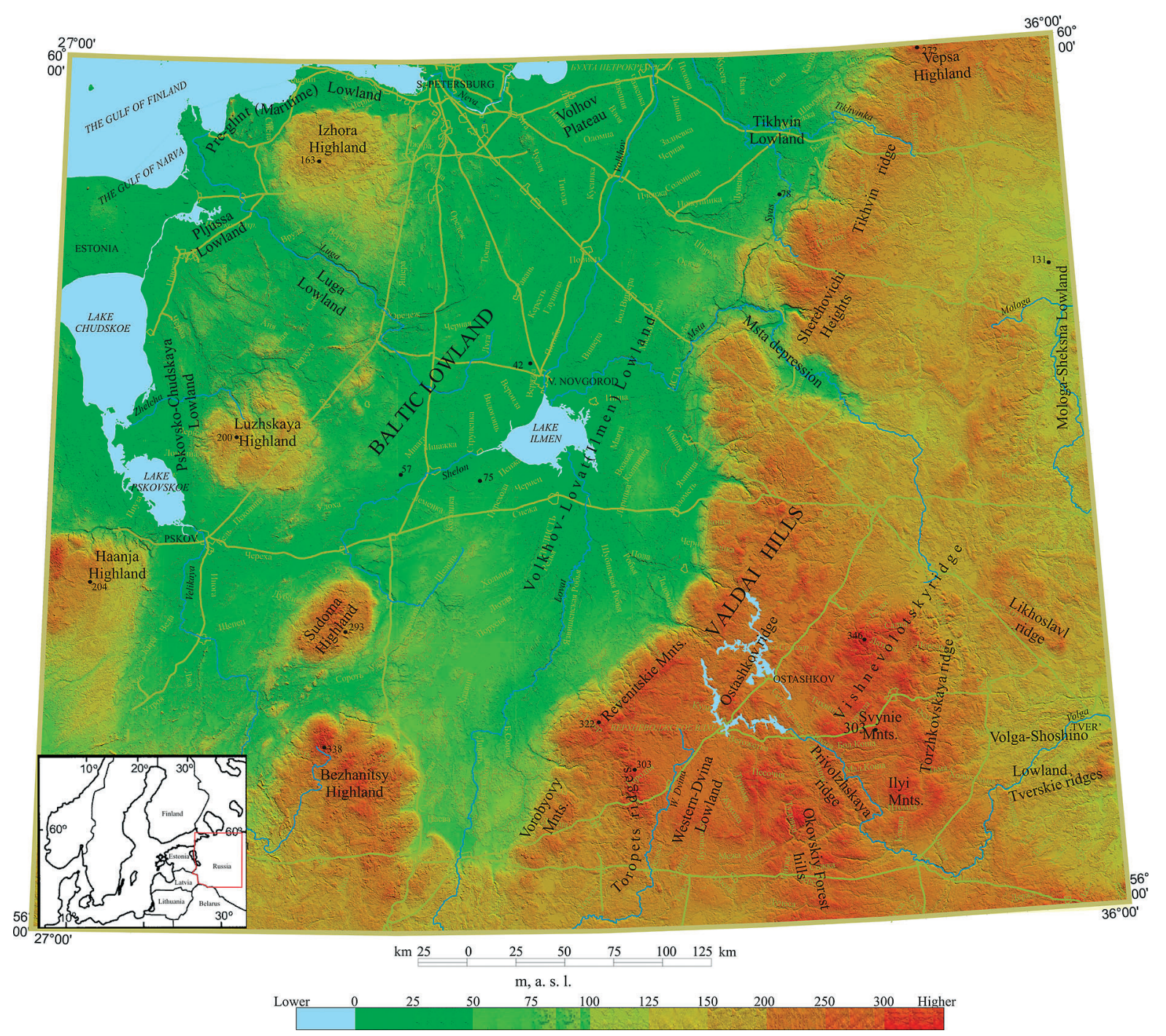

Fig. 1. Scheme of orography (compiled by Krotova-Putintseva A.Y.)

the topography and extends from the Syas River to the Narva River. It is composed of the Ordovician limestones and rises above the pre-glint lowland at 5-40 m; the absolute height of its upper edge reaches 100-120 m (Koporie village - Krasnoye Selo).

South of glint, there are Izhora Highland and Volkhov Plateau from 25 to $168 \mathrm{~m}$ high. In the western and central parts of the study area, an alternation of extensive lowlands (Volkhov-Lovat or Ilmen, Pskov-Chudskaya) with absolute heights from 20 to $120 \mathrm{~m}$ and isolated highlands of contrast hummocky-lacustrine morphology, rising above the surrounding area at 100-220 m (Luga, Haanja, Sudoma, and Bezhanitsy) is observed.
The Valdai Hills are separated from the Baltic Lowland by Valdai-Onega (Carboniferous) scarp with relative heights of $25-125 \mathrm{~m}$, which extends from the southern shore of Lake Onega (outside the study area) to the headwaters of the Lovat River. The Valdai Hills consist of individual ridges and their massifs (Tikhvin, Ostashkov, Vyshnevolotsky ridges, Toropets, Sherekhovichi heights, Vorobyovy, Revenitsy, Svinie and Ilyi mountains, Okovsky Forest hills) and depressions among them. At Vyshnevolotsky ridge, in the interfluvial area of the Tsna (river Msta Basin) and Poved (river Tvertsa Basin) rivers near Repishche village, the highest point of the Valdai Hills and the whole study area, 
$346 \mathrm{~m}$ a.s.l., is situated. Southward and southeastward, topography of the Valdai Hills gradually flattens and is replaced by plains in the Tvertsa, Mologa, and Volga river basins. Lower parts of this plain known as the Volga-Shoshino, Middle Mologa, and Mologa-Sheksna lowlands with elevations of 125-170 m a.s.l. Areas of hummocky glacial relief are also present (Tver, Likhoslavl, Torzhok, Lesnoy ridges etc.).

The territory has an extensive river network. The Valdai Hills form the watershed between catchment basins of the Baltic (Neva, Volkhov, Luga, Narva, Velikaya, Shelon, Lovat, Msta, and Western Dvina rivers) and Caspian (Volga, Mologa, and Chagoda) seas. There are numerous lakes varied in size, shape, and origin in the study area. The largest of them are Ladoga, Chudskoye, Pskov, Ilmen. A large number of medium and small lakes is concentrated in the Lake District of the Valdai Hills (Lakes Seliger, Shlino, Piros), as well as on island highlands of the Baltic Lowland (Lake Zhizhitskoe etc.). In addition, karst lakes are found on the Valdai Hills.

\subsection{Geomorphology}

The modern landscape is diverse in genesis, but the main factor in its formation was accumulative (in a less degree denudational) activity of glaciers and their meltwaters. In terms of age and, partially, morphology (degree of topography "freshness"), observed glacial and aqueoglacial relief can be divided into three geomorphological provinces (Fig. 2): (1) province of Moscovian glaciation, (2) province of Podporozhye (Early Valdaian) glaciation and (3) province of Ostashkovian (Late Valdaian) glaciation (Malakhovsky \& Markov, 1969; Kirikov \& Yanovskiy, 1989).

The province of glacial and aqueoglacial relief of the Ostashkovian (last) glaciation (MIS 2) is characterized by fresh-looking landforms, large quantity of lakes, and lack of cover formations. After the predominance of one or another relief formation processes and with respect to the glacier edge, the province is divided into three zones: (1) proximal (inner), (2) zone of marginal glacial formations (major ice-marginal zone), (3) and distal (outer) (Kirikov \& Yanovskiy, 1989).

The proximal zone occupies the largest part of the area. In the east, it is bordered by the major icemarginal belt, which is located on the western edge and at the foot of the Valdai Hills. This zone is characterized by widely spread till and glaciolacustrine plains developed in the course of degradation of the Late Valdaian glacier and inflow of large amounts of meltwaters hampered up by the dam of the major ice-marginal belt. Accumulative hummocky and hummocky-ridged glacial and aqueoglacial relief is represented by both in the form of large interlobate highlands and small ridges and massifs. Three geomorphological regions with a specific outlook of both modern and ancient topography are distinguished within the proximal zone: Baltic-Ladoga (accumulative and abrasion plains and isolated accumulative highlands), Volkhov-Lovat (denudation plateau, abrasion-accumulative plains with linear accumulative formations), and Izhora-Bezhanitsy (isolated denudation and accumulative highlands and abrasion-accumulative plains with ridges and kame areas) (Malakhovsky \& Markov, 1969; Kirikov \& Yanovskiy, 1989; Svendsen et al., 2004; Kalm, 2010).

The ice-marginal zone (major ice-marginal belt) is a strip of hummocky glacial accumulative terrain formed mainly during the Vepsian and Krestetsky phases. This zone stretches along the eastern and south-eastern limits of the research area, from Lake Onega (beyond the study area) to the Lovat River head (Kirikov \& Yanovskiy, 1989; Svendsen et al., 2004; Kalm, 2010).

The distal (outer) zone adjoins the major icemarginal belt from the outer (eastern) side. It is represented by accumulative undulating fluvioglacial plains: their surface gradually decreases to the south and south-east from 180 to $140-120 \mathrm{~m}$ a.s.l. The transition from the ice-marginal zone to the distal is gradual. In this case, hummocky topography flattens and is replaced by fluvioglacial and then glaciolacustrine plains, among which individual moraine hills and ridges, kames, eskers are present (Malakhovsky \& Markov, 1969).

The province of glacial and aqueoglacial relief 


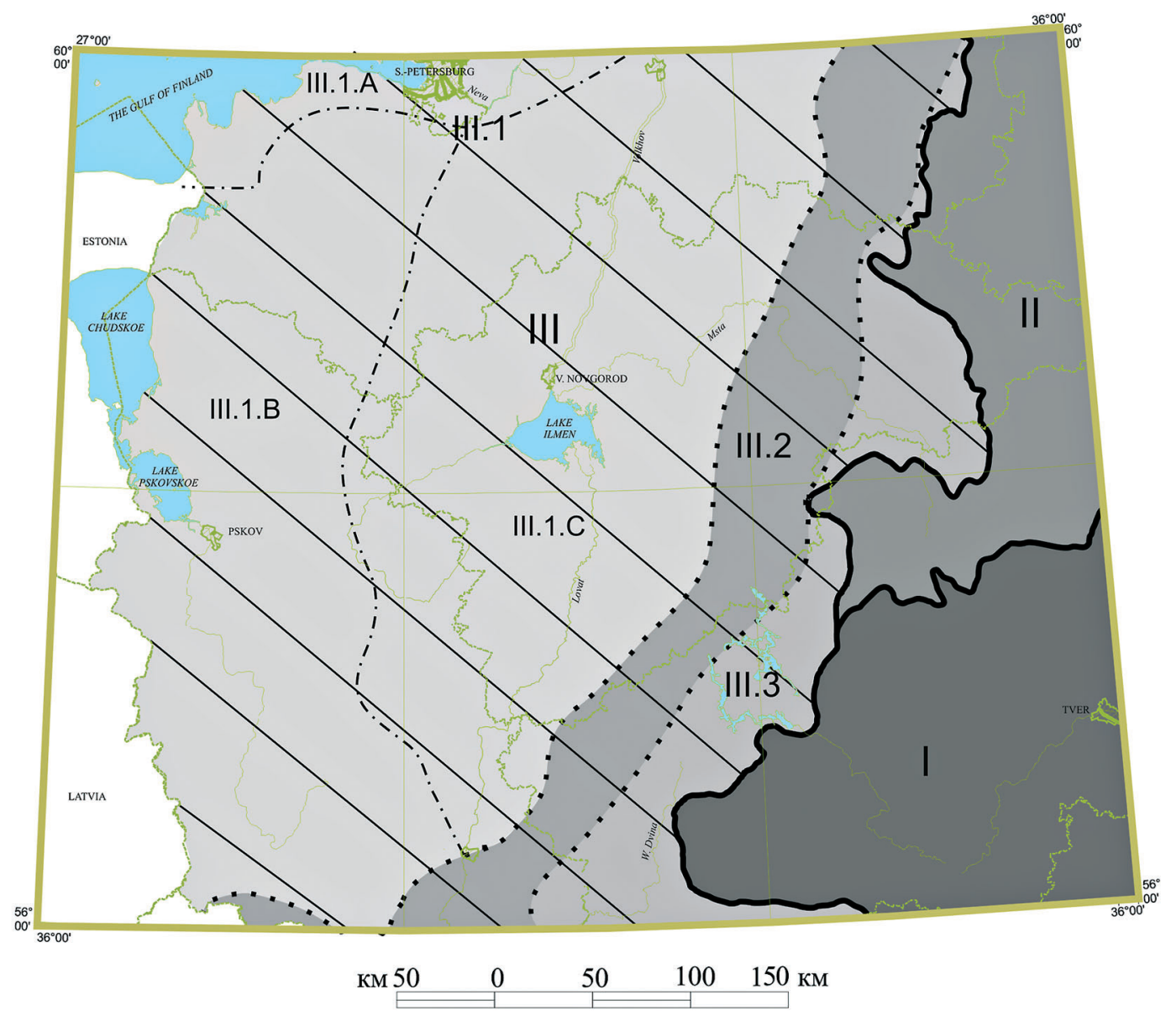

I Province of glacial and aqueoglacial relief of Moskovian glaciation

II Province of glacial and aqueoglacial relief of Podporozhye glaciation

III Province of glacial and aqueoglacial relief of Ostashkovian glaciation

Proximal zone

III.1 III.1. A Baltic-Ladoga region

III.1.B Izhora-Bezhanitsy region

III.1.C Volkhov-Lovat region

III.2 Ice marginal zone (major ice-marginal belt)

III.3 Distal zone

Boundaries of: provinces

zones

regions 
of the Podporozhye glaciation (MIS 4) is located in the north-east of the studied area, mainly within the Mologa-Sheksna lowland. Hummocky and hummocky-ridged moraine topography, as well as accumulative moraine, fluvioglacial, and glaciolacustrine plains is developed within the province. As the province of the Early Valdaian glaciation is a part of the distal zone of the Late Valdaian glaciation, the landforms within its limits are largely washed out and overlapped by fluvioglacial deposits of the last glaciation. It is possible that the absence of large forms is due to the glacier dynamics, thermal regime on its bed.

The province of glacial and aqueoglacial relief of the Moskovian glaciation (MIS 6) occupies the south-eastern part of the study area within the Valdai Hills and Volga-Shoshino lowland. Thin cover formations represented by sandy loam and loam are developed here. Landforms of the Moskovian glaciation have smoothed surface as they have endured long-lasted solifluctional, erosional and periglacial processes. This area is characterized by almost total absence of lakes, the latter are drawn down by moving back erosion; their basins are filled with sediments or peat. The remaining lakes typically occupy only a small part of their basins. The river network is highly branched; the main rivers have wide valleys, valley sandrs are developed (Kirikov \& Yanovskiy, 1989). Hummocky moraine elevations with groups of large hilly-ridged forms, moraine-sandr and glaciolacustrine plains are distinguished in the relief.

\section{Preglacial relief}

Main peculiarity of geological structure of this territory is gently sloping monoclinal bedding of bedrock with weak inclination to the south and south-east. Accordingly, successive alternation of ancient sedimentary strata and younger ones, facing the pre-Quaternary surface up the dip, takes place in the same direction (Sidorenko et al., 1971).

Preglacial denudation relief, mostly covered by the Quaternary sediments of uneven thickness, formed on the Paleozoic terrigene and carbonaceous sedimentary rocks (in the farthest northwest on the
Vendian, while in the east on the Mesozoic). The bedrock has gently sloping monoclinal bedding and different denudation resistance, therefore as a result of long continental denudation since the Middle Mesozoic period, cuesta uplands (plateau and plains) were formed in this area by the beginning of Neogene (Spiridonov, 1978; Malakhovskiy \& Markov, 1969). They are the "Cambrian" and "Devonian" plains, and the "Ordovician" and "Carboniferous" plateau (Fig. 3). It is significant that names of these elements correspond not to the time of their formation, but to the age of sediments.

The "Cambrian" plain, worked out in Kotlinian and Lontovasian clays of the Vendian and Lower Cambrian, occupies the lowest hypsometric position. Flat Baltic-Ladoga depression and land areas along the southern coast of the Gulf of Finland, Lake Ladoga and Karelian Isthmus are confined to it. Altitudes of this level vary from -50 to $50 \mathrm{~m}$ a.s.l. (Kirikov \& Yanovskiy, 1989).

The "Ordovician" plateau forming the next level is composed of limestone and is separated from the previous level by the Baltic-Ladoga scarp, known as glint (Miidel \& Raukas, 2005). Glint, expressed in the present relief as well, is composed in its lower part of the Cambrian clays; the Cambrian-Ordovician sand stratum overlapped by the Ordovician limestone occurs above (Malakhovskiy \& Greiser, 1987). The scarp is oriented sublatitudinally, according to the general strike of the Ordovician rocks, changing its strike in Koporie-Kingisepp area to submeridional. Glint has different height and width. In Krasnoye Selo - Koporie area, its height is 60-80 m, and width $4.5-7 \mathrm{~km}$. Glint is poorly expressed in the interfluve of the Narva and Luga, Mga and Tosna rivers, where its height does not exceed 17-20 $\mathrm{m}$ a.s.l. and width $1-2 \mathrm{~km}$. The "Ordovician" plateau surface slopes gently toward the south; in the east - south-east and toward the scarp it has maximum altitudes of 125-150 m a.s.l. near Kotly village (Gatchina), wherefrom it gradually decreases to the west and east to altitudes of 30-60 m a.s.l. (Kirikov \& Yanovskiy, 1989).

The "Devonian" plain consists of sandyargillaceous, carbonate and interstratifying sandyargillaceous and carbonate sediments of the Middle 


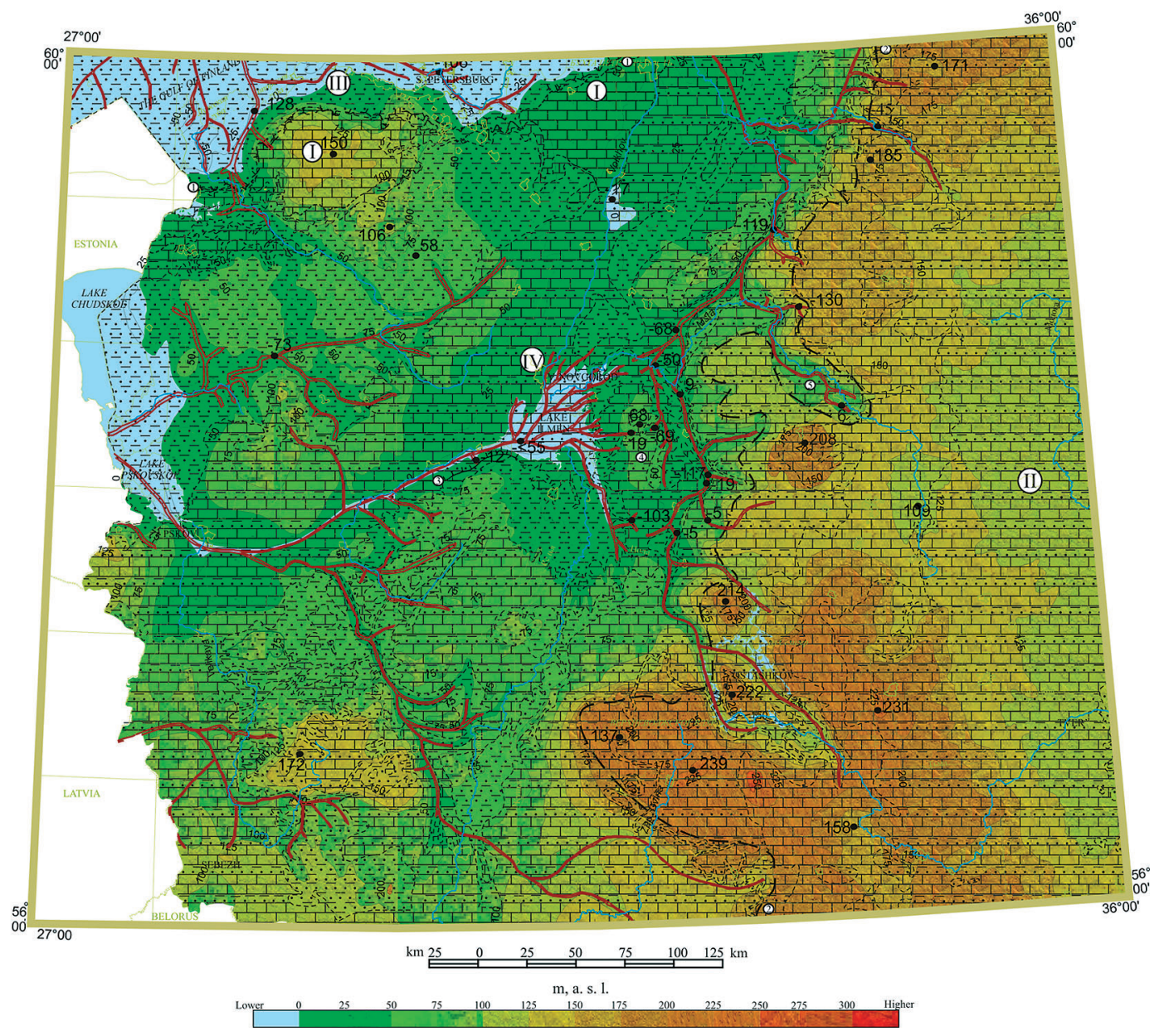

\section{LEGEND}

Carbonate rocks

Interstratifying of carbonate and sandy-argillaceous rocks

Sandy-argillaceous rocks

$\therefore$ Sandstone

Assumed paleovalleys

$\sqcap$ Rivers

$1_{150}$ Isohypses of the sub-Quaternary surface, $m$ a. s. 1.

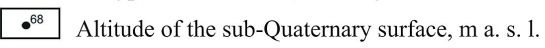

Main landforms:

Denudational plateau: (I) - «Ordovician», (II) - «Carboniferous»

Denudational plains: (III)- «Cambrian», IV - «Devonian»

๑ - Beglovskiy swell

$\odot$ - Msta hollow

-_- Denudational scarps and slopes:

๑ - Ordovician (Baltic-Ladoga)

๑ - Carboniferous (Valdai-Onega)

๑ - Ilmen

Fig. 3. Map of the pre-Quaternary relief 
and Upper Devonian period. The plain stretches north-easterly according to the Devonian deposits strike. Its altitudes vary from 0 to $75 \mathrm{~m}$ a.s.l. The lowest part of the plain is occupied by the Volkhov and Shelon rivers and also by the Lake PskovChudskoe depression, which is near-meridionally oriented. Carbonate Devonian rocks expose along the south-western Lake Ilmen coast, forming the Ilmen scarp (klint). Its altitude is about $20-25 \mathrm{~m}$ a.s.l., length is about $18 \mathrm{~km}$. There are Loknovskoe rise (150-160 m), and rises under the Luga (105$110 \mathrm{~m})$ and the Bezhanitsy highlands (125-170 m) within the "Devonian" plain. South-eastern part of the plain rises from 50 to $150 \mathrm{~m}$ a.s.l. (Kirikov \& Yanovskiy, 1989).

The "Carboniferous" plateau, which is located in the eastern part of the study area, forms the highest relief level. Plateau is mostly composed of the Carboniferous limestone, and in the southern part of the Upper Devonian interstratifying sandyargillaceous and dolomite sediments. Its surface inclines south-eastward according to strata dip of the western flank of Moscovian syneclise. The highest altitudes concentrate along the western edge of the plateau and reach 150-170 m a.s.l. in the northern part, and 200-225 $\mathrm{m}$ in the southern part. In some places, altitudes reach up to $240-277 \mathrm{~m}$. In the east, altitudes smoothly descend to $75-100$ $\mathrm{m}$ a.s.l. Plateau's edge is dissected by modern and ancient valleys and glacial channels (Kirikov \& Yanovskiy, 1989). The gulf-like Msta hollow, trending south-easterly, is the most significant depression that cuts deep in plateau. It has erosional genesis.

Plateau is separated from the "Devonian" plain by the so-called "Carboniferous" (Valdai-Onega) scarp, formed in the Carboniferous and Devonian rocks. Its orientation corresponds to the north north-east strike of the Carboniferous rocks. Toward the south it trends south-easterly. The relative height of the scarp changes from 75 to $125 \mathrm{~m}$, width is 10-15 km. "Carboniferous" scarp, covered by the Quaternary deposits, is expressed in contemporary topography as the Valdai Hills slope.

\section{Reconstruction of the ancient river network}

The sub-Quaternary surface of the study area and adjacent territories is dissected by deeply-incised valleys (-106 m a.s.l. in Saint-Petersburg, $-130 \mathrm{~m}$ a.s.l. in Liubytino, $<-55 \mathrm{~m}$ a.s.l. in Lake Ilmen depression) with V-shaped cross-sections (Verbitskiy et al. 2007). We assume that the preglacial river erosion was the main factor of deep incisions formation, albeit their genesis could be explained in different ways (see Malakhovskiy \& Fedorov, 1984; Malakhovskiy, 1995; Rattas, 2007; Vaher et al., 2010).

It is considered, that most of the deeply-incised valleys of the Baltic region were formed in the Late Paleogene and Neogene. Main discharge of the paleoriver network went through the Baltic Sea depression (Kvasov, 1975; Klige, 1980; Bijlsma, 1981; Malakhovskiy \& Fedorov, 1984; Gibbard, 1988; Grigelis, 1991; Vaher et al., 2010). The PreQuaternary drainage system of the study area had two general flow directions. The first one was related to the main valley, stretched along the western side of the Valdai Hills. That valley is characterized by the deepest marks ( $-130 \mathrm{~m}$ a.s.l. in a borehole near Liubytino). Probably, it was a base of the drainage system with outlet to the north (around present Lake Ladoga) and then into the paleoriver system of the Baltic Sea bottom (Verbitskiy et al. 2007). The second flow course is due to watershed of the Beglovskiy swell area, which is located to the east of Lake Ilmen depression, with westward drainage via a paleovalley of the proto-Shelon River (Verbitskiy et al. 2007).

Analysis of borehole data and available schemes of the pre-Quaternary surface structure for a larger territory allowed a new reconstruction of paleoriver system in the modern Ilmen Lake area. In the preQuaternary surface topography, there is a hollow south-westward from the Lake Ilmen depression. We infer that this hollow, confined by the 25 isoline, was occupied by the ancient valley with marks of $<55,12,60 \mathrm{~m}$ b.s.l. The tributaries that drained the Lake Ilmen depression, and the Luga and Bezhanitsy highlands discharged into this 
paleovalley. Drainage took place via the Shelon Cherekha - Piuza Rivers and further towards the Gulf of Riga depression.

\section{Conclusions}

Analysis of the relationship between preglacial topography and modern relief indicates that the latter depends on the pre-Quaternary topography. Distinguished in modern relief, lower western and higher eastern parts are distinguished in the preQuaternary relief as well (Figs. 1 and 3).

Main elements of the preglacial denudational relief are the "Cambrian" plain, formed in the areas of the Upper Vendian and Lower Cambrian clay rocks distribution, and the "Devonian" plain, confined to the development areas of mostly sandyclayey Devonian deposits, as well as the "Ordovician" plateau associated with the areas of the denudation-resistant Ordovician limestones and the "Carboniferous" plateau associated with outcrops of the Carboniferous limestones and the Upper Devonian dolomites, alternating with sandy-clayey rocks.

Mentioned above bedrock elements correspond to modern relief. Pre-glint lowland corresponds to the "Cambrian" plain, and Volkhov-Lovat lowland to the "Devonian" plain. The "Carboniferous" plateau is a socle of the Valdai Hills; Izhora highland and Volkhov plateau are associated with the "Ordovician" plateau.

Denudational scarps of the pre-Quaternary relief are also expressed in modern relief as slopes of the Valdai Hills and Izhora highland.

Contemporary rivers inherit paleovalleys only in some parts - for example, proto-Msta, protoPolomet Rivers. In most cases deep incisions are not expressed in modern relief.

Analysis of altitude marks of the pre-Quaternary deposits surface and available material on the structure of this surface in adjacent territories suggests that, in the Neogene, drainage from the Ilmen lowland territory was to the west. At present, Lake Ilmen is drained by the Volkov River, which flows northward into Lake Ladoga.

Based on the analysis of the structure of the preQuaternary and modern relief, it is possible to conclude a quiet tectonic regime. Further investigations should be aimed at studying relationship between glacial events and preglacial relief. To reveal the causes of deep incisions formation, geological history of the study area and adjacent regions should be considered in plate-tectonic framework.

\section{Acknowledgements}

We thank Pertti Sarala and two anonymous reviewers for their comments which improved the manuscript. We also thank our colleges at VSEGEI for assistance.

\section{References}

Auslender, V.G. 1998. Buried ancient valleys of Saint-Petersburg area. In: Main results of the Quaternary period study and outlines for further investigations in XXI century. Abstracts. Saint-Petersburg, p. 311. (in Russian).

Bijlsma, S. 1981. Fluvial sedimentation from the Fennoscandian area into the north-west European Basin during the Late Cenozoic. In: van Loon, A.J. (ed.) Quaternary Geology: a Farewell to A.J. Wiggers. Geologie en Mijnbow 60, 337-345.

Burde, A.I., Strelnikov, S.I., Mezhelovskiy, N.V., Sokolov, P.I., Starchenko, V.V., Toporets, S.A. 2000. Three centuries of geological cartography in Russia. Moscow - St. Petersburg. (in Russian)

Gibbard, P.L. 1988. The history of the great northwest European rivers during the past three million years. In: Shackleton, N.J., West, R.G. \& Bowen, D.Q. (eds) The Past Three Million Years: Evolution of Climate Variability in the North Atlantic Region. The Royal Society, London, pp. 559-602.

Goretskiy, G.I., Chebotareva, N.S. \& Shick, S.M. 1982. Moscovian glacial cover of Eastern Europe. Nauka, Moscow. (in Russian)

Grigelis, A.A. (ed.) 1991. Geology and geomorphology of the Baltic Sea. Explanatory note of the geological maps, scale 1:500 000. Nedra, Leningrad. (in Russian)

Kalm, V. 2010. Ice-flow pattern and extent of the last Scandinavian Ice Sheet southeast of the Baltic Sea. Quaternary Science Reviews, 44, 51-59

Kirikov, V.P. \& Yanovskiy, A.S. (eds.) 1989. Geological map of the USSR. Scale 1:1000 000 (second generation). Explanatory note. Sheet 0-(35), 36 - Leningrad. Geology ministry of the USSR, VSEGEI, PGO "Sevzapgeologia", Leningrad. (in Russian)

Klige, R.K. 1980. Ocean level in geological past. Nauka, Moscow. (in Russian)

Kvasov, D.D. 1975. Late Quaternary history of big lakes and inland seas of Eastern Europe. Nauka, Leningrad, pp. 30- 
31. (in Russian)

Malakhovsky, D.B. \& Markov, K.K. (eds.) 1969. Geomorphology and Quaternary Deposits of the Nortwestern Part of the USSR (Leningrad, Pskov and Novgorod Regions). Nauka, Leningrad. (in Russian).

Malakhovskiy, D.B. \& Fedorov, B.G. 1984. On the age and genesis of depressions in the North of Europe. In: Age and genesis of depressions in shelf areas and river valleys history, pp. 134-140. (in Russian)

Malakhovskiy, D.B. \& Greiser, E.L. 1987. The Baltic-Ladoga scarp. Geomorphology 1, 94-98. (in Russian)

Malakhovskiy, D.B. 1995. Problems of genesis and age of topography of the north-western Russian Plain. Geomorphology 2, 44-53.

Miidel, A. \& Raukas, A. 2005. Slope processes at the North Estonian Klint. Proceedings of the Estonian Academy of Sciences, Geology 54, 209-224.

Petrov, O.V, Verbitskiy, V.R., Kiselev, E.A., Putintsev, V.K. \& Krotova-Putintseva, A.Y. 2007. State geological map of the Russian Federation at 1:1000 000 scale (history, results and work objectives). VSEGEI, Saint-Petersburg. (in Russian)

Rattas, M. 2007. Spatial distribution and morphological aspects of eskers and bedrock valleys in North Estonia: implications for the reconstruction of a subglacial drainage system under the Late Weichselian Baltic Ice Stream. In: Johansson. P. \& Sarala, P. (eds.) Applied Quaternary research in the central part of glaciated terrain. Geological Survey of Finland, Special Paper 46, 63-68.

Sidorenko, A.V., Selivanova, V.A. \& Koffman, V.S. (eds.) 1971. Geology of the USSR. Vol. I. The Leningrad, Pskov and Novgorod regions. Geological description. SZTGU, Nedra, Moscow. (in Russian)

Spiridonov, A.I. 1978. Geomorphology of European part of USSR. Visshaya shkola, Moscow. (in Russian)

Structure and dynamics of the last glacial cover of Europe, 1977. Nauka, Moscow. (in Russian)

Svendsen, J.I., Alexanderson, H., Astakhov, V.I., Demidov, I., Dowdeswell, J.A., Funder, S., Gataullin, V., Henriksen, M., Hjort, C., Houmark-Nielsen, M., Hubberten, H.W., Ingólfsson, Ó., Jakobsson, M., Kjær, K.H., Larsen, E., Lokrantz, H., Lunkka, J.P., Lysa, A., Mangerud, J., Matiouchkov, A., Murray, A., Moller, P., Niessen, F., Nikolskaya, O., Polyak, L., Saarnisto, M., Siegert, C., Siegert, M.J., Spielhagen, R.F. \& Stein, R. 2004. Late Quaternary ice sheet history of northern Eurasia. Quaternary Science Review 23, 1229-1271.

Vaher, R., Miidel, A., Raukas A. \& Tavast, E. 2010. Ancient buried valleys in the city of Tallinn and adjacent area. Estonian Journal of Earth Sciences 59, 37-48.

Verbitskiy, V.R. et al. 2007. State geological map of Russian Federation, scale 1:200 000. Sheet O-36-XIV (Velikiy Novgorod). Explanatory note. Saint-Petersburg. (in Russian) 